Bryn Mawr College

Scholarship, Research, and Creative Work at Bryn Mawr College

2015

\title{
Beyond Remittance: Evading Uselessness and Seeking Personhood in Fouta Djallon, Guinea
}

Susanna Fioratta

Bryn Mawr College, sfioratta@brynmawr.edu

Let us know how access to this document benefits you.

Follow this and additional works at: http://repository.brynmawr.edu/anth_pubs

Part of the Social and Cultural Anthropology Commons

\section{Citation}

S. Fioratta, "Beyond Remittance: Evading Uselessness and Seeking Personhood in Fouta Djallon, Guinea," American Ethnologist 42.2 (2015): 295-308.

This paper is posted at Scholarship, Research, and Creative Work at Bryn Mawr College. http://repository.brynmawr.edu/anth_pubs/11

For more information, please contact repository@brynmawr.edu. 
Beyond Remittance: Evading Uselessness and Seeking Personhood in Fouta Djallon, Guinea

\author{
Susanna Fioratta \\ Bryn Mawr College
}

Mailing address:

Department of Anthropology

Bryn Mawr College

$101 \mathrm{~N}$. Merion Avenue

Bryn Mawr, PA 19010

Email address:

sfioratta@brynmawr.edu

Abstract: Remittance networks built through transnational migration have transformed local economies as well as social lives in many parts of the world. In this article, I examine the relationship between transnational migration and local business practices for ethnic Fulbe people from the Fouta Djallon highlands of Guinea. Although some Fouta Djallon residents have withstood poverty with the help of remittances from migrant relatives, many migrants fail to earn money abroad. But despite slim chances of success, migration remains a popular undertaking, especially for young men. Meanwhile, non-migrants engage in small business projects that yield little or no income. Analyzing informants' critiques of "uselessness," I argue that both nearimpossible migration quests and seemingly irrational business practices are linked by a common desire to achieve social personhood under adverse structural conditions. Apparent striving for success mitigates failure to send or earn money, even while reproducing ideals of mobility and entrepreneurship in responsible personhood.

[remittances, transnational migration, personhood, Guinea, Fulbe/Fulani, West Africa] 
Acknowledgments: Fieldwork in Guinea and Senegal from 2009-2010 was funded by the International Dissertation Research Fellowship of the Social Science Research Council, the Wenner-Gren Foundation Dissertation Fieldwork Grant, the National Science Foundation Doctoral Dissertation Improvement Grant in Cultural Anthropology, and Fulbright-IIE. A Yale University Dissertation Fellowship and a Provost's Postdoctoral Fellowship in the Department of Anthropology at the University of South Florida supported my development of the ideas presented here. I am grateful to Mike McGovern, Doug Rogers, Kamari Clarke, Allison Alexy, Becky Furth, and Bruce Whitehouse for their comments on different versions of this article. I also thank Angelique Haugerud and the anonymous $A E$ reviewers for their insightful feedback. In Guinea and Senegal, I thank Dr. Amadou Bano Barry and his colleagues in the Sociology Department at Lansana Conté University of Sonfonia-Conakry, Thierno Saidou Agne Diallo, all the residents of "Hamdallaye" and "Daande Caanguel," and the many others who generously supported this research with their time and hospitality.

One afternoon in February 2010, I sat on the street of a residential neighborhood in Dakar, Senegal and drank tea with several young ethnic Fulbe men who had come to the city from the Fouta Djallon highlands of the Republic of Guinea. Two of the men worked as security guards at the nearby houses. The rest were currently unemployed, but hoping to get work as guards — or as anything — should the opportunity arise. Since I had recently come from Guinea, they asked me the question Guinean Fulbe living in Dakar often asked me: which place did I prefer, Guinea or Senegal? I got a laugh with my usual answer - that I liked Guinea because I liked to eat taro, a food that many people from the Fouta Djallon both love and love to joke 
about, associating it with the most rustic village life. Then, I turned the question back to them: which place did they prefer? One of the young men, Alimou, ${ }^{1}$ began to rhapsodize about Guinea's superiority to Senegal: "In Guinea, you can eat without paying. You can do what you want. Even if you don't work, you can just walk around and there is always plenty to eat." "Well, then, why are you here?" I asked Alimou. The other young men laughed and echoed my question. Alimou tried a few times to change the subject, but the others repeatedly called him back to it, saying, "If Guinea is so good, why are you here?"

"Seriously," Alimou said, "if I could go to America or Switzerland and get a lot of money, what I'd really want would be to go right back to Guinea, build a road to the village, build a nice house, and eat taro and bananas. Of course being there is better than being here! But to buy clothes and shoes, to have money to build a house, you have to make money. And there is no way to make money if you stay in Guinea."

Another of the young men, Mamadou Korka, interrupted him. "People leave Guinea and try for twenty years to make money and they don't succeed!" he cried. "Why do you think that you will succeed?"

On the surface, there was no mystery as to why most of the Guinean Fulbe men and women I met in Senegal had left their homes in the Fouta Djallon, just as there was no mystery why most Fouta Djallon households I knew could claim members working outside of Guinea: people wanted and needed to make money. Young men left to seek (dabbugol, in the Pular language spoken in the Fouta Djallon) not just their own fortunes, but also those of the people they were expected to help support: their parents and older family members, their current and future wives and children, and, more broadly, the villages, towns, and regions they called home. Women left the Fouta Djallon to join husbands abroad, and they too sought to make money, 
either in partnership with their husbands or on their own. Though rich in natural and mineral resources, Guinea is one of the poorest countries in the world. But within Guinea, the Fulbedominated Fouta Djallon has a reputation for being more prosperous than the country's other regions. Remittances from family members near and far have provided many Fouta Djallon residents with new houses, cars or motorbikes, and pilgrimages to Mecca, while associations of expatriates contribute money to build or renovate hometown mosques, schools, health centers, and other forms of infrastructure. ${ }^{2}$ Young men like Alimou left home aspiring to make money. Lamarana, another Guinean Fulbe man I interviewed in Senegal, echoed Alimou's words:

When we've left Guinea and we've gone abroad, what we want is to get money. Because if you've got money, then you've got everything. Because you hear people say that money is the key to the world...if you'd had it back home, you would not have left.

Both Alimou's and Lamarana's comments reflect the widespread sentiment in the Fouta Djallon that migrants were primarily motivated by the desire to earn money and send or bring it home. And yet, as Mamadou Korka pointed out, migrants often did not succeed in making money, even after years of trying. In Dakar, one of the most popular destinations for Fouta Djallon migrants, some Guinean Fulbe residents ran prosperous businesses and sent their children to the university; however, others worked at menial, low-wage jobs, barely earning enough to eat one meal a day, let alone send money home to their families. And though many people did send home remittances in the form of money and gifts, they often managed to do so only for particular occasions_-like weddings, births, illness, and funerals — and sometimes only by borrowing from friends in less straitened circumstances. When making money was so difficult 
and sometimes impossible, why did young men like Alimou and Lamarana insist that only the promise of making money kept them away from the Fouta Djallon, where they otherwise wanted to be? Would they truly have preferred to stay home, had economic necessity not driven them away? Likewise, how did their parents, siblings, wives, and friends back in Guinea manage their daily lives without much income, either in remittances or from their own earnings? Could they really, as Alimou declared, "eat without paying"? If money is the "key to the world," why would possessing it motivate someone not to travel the world, but rather to stay home, as Lamarana suggested?

In this article, I illustrate that the answers to these questions lie in understanding how particular notions of personhood infuse practices of migration, work, and money-earning for people in a transnational remittance economy. I argue that Fouta Djallon migrants embark on their journeys abroad against seemingly impossible odds not only to earn and send home money but also in quest of social personhood - a desire they share with their family members who stay behind and endeavor not to appear "useless" by engaging in small, often unprofitable, business projects. I show that when the experiences of migrants are examined in juxtaposition with the economic activities undertaken by people in migrant-sending communities, the importance of social personhood for all individuals becomes clearly evident. Beyond aspirations of making money, going abroad allows migrants to present themselves as striving to be responsible members of the communities they leave behind - even if the reality of their experiences leaves their ideals of personal success unfulfilled. Likewise, individuals who stay in their hometowns and engage in small-scale entrepreneurial activities that earn almost no money at all are performing a similar notion of responsible personhood. People desire wealth, but they rarely 
manage to attain it, whether at home or abroad. Instead, by either striving invisibly at a distance, or else working industriously at home, they seek the respect accorded a responsible person.

My argument draws on anthropological theories of personhood in African contexts and beyond, bringing these into conversation with the growing literatures on transnational migration and youth transitions to adulthood in conditions of economic uncertainty. Following Marcel Mauss's classic essay tracing the notion of the person or self through time and space, anthropologists have engaged in various ways with the concept of "the person," referring alternately to an interior awareness of self, and to the enactment of social roles and responsibilities_-for Mauss, moi and la personne morale, respectively (Fortes 1973, La Fontaine 1985, Jackson and Karp 1990, Strathern and Stewart 1998, McIntosh 2009; cf. Mauss 1979[1938]). Paul Riesman, who wrote extensively about personhood among Fulbe groups in Burkina Faso, effectively brought these aspects together, asserting that "being a person and understanding what a person is are the same sort of process; that being a person is essentially a process of making meaning" and therefore necessarily involves connectedness to other individuals, with whom meaning is communicated and shared (Riesman 1992:10). Following Riesman, I focus on personhood as a social concept that reflects individual desires as well as shared expectations. I use the term "personhood" not as the gloss of a comparable Pular language word, but rather to describe more broadly the constellation of consciousness, roles, and responsibilities that motivate Guinean Fulbe migrants and non-migrants alike. Thus, I emphasize the processual aspects of personhood, examining what individuals hope to become and how they relate to others over the course of their lives (cf. Carsten 1995). I understand this process as an agentive one, whereby individuals actively "seek" (dab6ugol) personhood, and their fortunes, at once. Guinean Ful6e migrants and entrepreneurs struggle to achieve and maintain ideals of 
respectable personhood in a context where global structural inequalities and increased policing of international borders make acquiring the material trappings of a successful life difficult, if not impossible.

Notions of personhood are especially salient in contexts of transnational migration, where conceptions of what makes a proper person reflect differences in perspective within migrant groups, as well as between them and host country nationals (Green 2011). Anthropological studies of migration have shown that migrants who are able to send remittances gain status and recognition in their hometowns, as well as in associations of fellow expatriates in their countries of residence (Trager 2001, Riccio 2011). And though aspiring migrants are often motivated by economic need, they may also desire to participate more fully in a globalized world where they see mobility as synonymous with modernity (Mains 2007, Lindquist 2009, Chu 2010). This article contributes to these literatures on personhood and migration, first, by showing how migrants strive to achieve recognition as responsible adult persons even when they are unable to send much, or any, money. And second, I show how particular ideals of successful personhood connect migrants who leave home to seek their fortunes with their family members who, in staying home, occupy their time with business projects that stand little chance of making money.

This article also contributes to anthropological work on youth transitions to adulthood in contexts of economic uncertainty. A number of studies, particularly those focusing on the experiences young men, have illustrated how boredom and waiting for opportunities that never materialize induce frustration and a sense of helplessness at being trapped in apparent limbo between youth and social adulthood. And yet, widespread unemployment and dispossession may also be productive of new political engagements, social connections, and cultural practices for those who are left with an overabundance of time and little else (Mains 2007, Jeffrey 2010, 
Masquelier 2013). In contexts where social adulthood is achieved largely through marriage and children, earning enough money to support a family and build a house is critical to becoming recognized as an adult person (Hansen 2005, Coulter 2009). In many cases, confronted with a dearth of formal sector employment, yet wanting to survive and also partake in cosmopolitan consumption, youth turn to independent entrepreneurship to participate in the global neoliberal economy (Scheld 2007, Martin-Iverson 2012). Here, I demonstrate how ideals of proper adult personhood motivate the entrepreneurial efforts of both migrants and non-migrants to earn money, or to appear to be trying to earn money.

Migration and entrepreneurship are the two preferred paths to earning money, and thereby achieving adult personhood, in Guinea's Fouta Djallon region, where I have worked and done research since 2002. My conversation with Alimou, Mamadou Korka, and their peers was one of many discussions of migration and money-earning that I witnessed during ethnographic research in the Fouta Djallon and among Guineans from the Fouta Djallon living in Dakar, Senegal, from July 2009-December 2010. Making up between 30 and 40 percent of Guinea's total population of 10.5 million, most contemporary Fouta Djallon residents consider themselves ethnic Fulbe and trace their ancestry back hundreds of years to nomadic pastoralists who settled in groups across West Africa. ${ }^{3}$ This deep history of mobility, reshaped and accelerated during an era of socialist state repression when between one quarter and one third of all Guineans left the country (1958-1984), has contributed to many Fouta Djallon residents' conceptions of themselves as people who move- which in turn figure in idealized notions of Fulbe personhood. ${ }^{4}$ Invoking distant historical narratives of nomadism as well as narratives of socialist era persecution and exile, some of my informants explained contemporary migration from the Fouta Djallon with the claim, "Moving is in our blood." Although I have found no reliable 
statistics comparing rates of migration between Fulbe and members of other Guinean ethnic groups, Fulbe do maintain a reputation within Guinea for being especially numerous among Guinean migrants abroad. Fulbe are also widely believed to dominate Guinea's commercial sector, partly as a result of their transnational business connections. The contours of my research reflected these conceptions of Fulbe mobility. I based my fieldwork at different times in a Fouta Djallon town that I call "Daande Caanguel," a smaller village that I call "Hamdallaye," and the heterogeneous West African metropolis of Dakar, which is both a migrant destination in its own right and a transit hub for Guineans en route to Europe, North America, the Gulf States, China, or further abroad in Africa. ${ }^{5}$ My research brought me into contact with the same people in different places, and with different groups of people connected to each other through kinship or hometown ties, despite geographic distance.

Mamadou Korka's challenge to Alimou, "Why do you think that you will succeed?" was a question that Alimou could not readily answer. Like many others who had come to Dakar to seek their fortunes, he had no marketable skills or training, and no seed money to start a business. He sometimes found odd jobs, mostly manual labor—work that he would have been ashamed to do at home, in full view of everyone he knew. He did not always have enough to eat. He shared a small room and a bed with three cousins around his own age, all in similar situations. To understand why Alimou considered that striving to make money abroad was worthwhile despite the many challenges involved, it is necessary to consider the broader social meanings, expectations, and motivations that shaped his individual search for success.

In what follows, I first examine the concept of remittances. I argue that focusing on remittances, in isolation from other forms of monetary or material gifts and exchange, is, first, virtually impossible in many contexts; and second, such a focus overlooks the significance of 
shared ambitions, desires, and notions of personal responsibility that link communities of people between small villages and larger cities, in home countries and abroad. I then examine the process of desiring and working toward a départ — the financial start in life that migrants told me they wanted - and how this aspiration fits in with other major life goals that mark the path toward responsible personhood. Subsequently, I present examples of the barely profitable economic activities pursued by those remaining in Guinea. Examining small business efforts as not strictly economic activities but also as social engagements, I analyze informants' critiques of "uselessness" to explain why individuals so often commit themselves to entrepreneurial projects that may seem economically irrational. Desiring to "leave a trace" in the world by building a house and parenting children, Fouta Djallon residents and migrants alike seek to achieve both wealth and responsible personhood.

\section{Remittances everywhere and nowhere}

Throughout much of the Fouta Djallon, connections to the world beyond Guinea seem plainly evident. Fouta Djallon residents I knew during fieldwork made frequent references to migration experiences in the course of daily conversation. Whether referring to their own past travels, expressing their desires to leave the country in the future, or showing photos of their absent family members, nearly everyone around me talked regularly of their relations with "the exterior." The landscape was dotted with houses built by individuals who were working or had worked abroad. Mosques, chain-link fences, and schools were often built and maintained by groups of expatriates organized to support their hometowns. Despite national poverty and perpetual political uncertainty, many people in the Fouta Djallon appeared to be managing fairly well with the help of money earned abroad. 
And yet, beneath this appearance of success abroad lies a more complex reality of striving and failure, reciprocity and responsibility. Money sent or brought by returning migrants plays a widely acknowledged role in hometown constructions, but remittances themselves do not easily fit into a single category distinct from other kinds of monetary movement and exchange that take place everyday among Fouta Djallon residents and expatriates. Remittances were important for many—-though not all—of my informants, but they were often impossible to see in isolation from either other sources of money or long-term social relationships of obligation and reciprocity.

Remittances have attracted considerable attention in policy and development circles for their growing role in the global economy, with recorded remittances often comparedfavorably - to dollar amounts of aid and foreign direct investment channeled from developed to developing countries (World Bank 2011). In these comparisons, remittances appear as a source of economic growth and political stability for developing countries and their citizens, achieved in accordance with neoliberal ideals of self-sufficiency. Nevertheless, World Bank-sponsored publications acknowledge actual global remittance figures to be virtually unknowable, with much money sent through informal, unofficial, unrecorded channels (e.g. Mohapatra and Ratha 2011:222, Ratha et al. 2011:5, 51, World Bank 2011:x, xvii-xviii). This is especially the case in Sub-Saharan Africa, where "only about half of the countries...collect remittance data with any regularity, and some major receivers of remittances report no data at all" (Ratha et al. 2011:5). The disjuncture between remittances as conducive to national development, on the one hand, and as shadowy unknowns, on the other, reveals how remittances may be politically or economically constructed in different ways. Rather than accepting the category of remittances at face value, I 
build on anthropological analyses that interrogate the meanings and conceptual boundaries of remittances and other forms of monetary obligation and responsibility in social contexts.

Hernandez and Coutin (2006) have argued that "expert" discourse serves to produce and define remittances as a measurable category. Situated at a "strange intersection of neoliberal economic strategies and grass-roots empowerment efforts," remittance discourse relies on particular accounting—or "discounting"—practices that represent remittances as cost-free national income, regardless of migrants' individual sacrifices or suffering (Hernandez and Coutin 2006:186). Money earned and sent by individuals, often at great personal cost to both migrants and their non-migrant families and with no assistance from any government, becomes the focal point of nation-states' efforts to harness transnational populations for political support or investment in national development (Baker-Cristales 2008, Mohan 2008). And yet, since "development" may have different meanings in different contexts, a community's use of remittances may not coincide with national or international ideals (Grigolini 2005, Trager 2001). Furthermore, as Anna Lindley (2010) has demonstrated in the case of Somalia, remittances may serve different political ends at different times, contributing to the intensification of conflict and, later, to defusing it.

Whatever the potential significance of migrants' earnings for national economies or political regimes, remittances are not necessarily a meaningful concept in every context, even where migration is frequent. As a researcher in Guinea and Senegal, I initially struggled to frame my questions about remittances in ways that would elicit the kinds of responses I thought I wanted. The French term transferts d'argent ("money transfers") was useful in a limited way, referring to sums received through agencies like Western Union or Moneygram; even when speaking Pular, people often inserted the word transfert into the conversation to refer to this kind 
of transaction. But transfert did not encompass other ways of sending and receiving money, as when people carried cash on return journeys. In Dakar, with money transfer fees ranging from 10 percent with informal, Guinean-owned services to between 20 and 100 percent at Western Union and Moneygram, people often preferred to entrust cash to close friends and relatives traveling to the Fouta Djallon. ${ }^{6}$ After some discussion, a research assistant suggested that I use the term kaalisi safaari-money from or of a journey— to refer to all the money that a person might receive from sources outside Guinea. When I tried this in an interview, asking a man whether he had ever received kaalisi safaari, he immediately pulled a 50 Euro note out of his pocket to demonstrate that he had; but he declined to tell the story of how he had obtained the 50 Euros, merely stating that Euros and US dollars were everywhere. Indeed, Euros, US dollars, and West African CFA francs circulated widely, and could be exchanged for Guinea francs even in smalltown shops. As the weeks and months passed, I developed other, more circuitous ways of asking informants when and how they received money from family members living outside of Guinea. But I also realized that remittances in the Fouta Djallon were often indistinguishable from other enactments of social obligations and reciprocity, motivated by individual desire as well as social expectation.

Anthropological studies of migration have consistently shown that remittances reflect the broader social lives of people who send and receive them. Beyond supplying people with often badly needed money, remittances also create social ties and solidarity between groups of people around the world (Cohen 2011, Monsutti 2005). Anthropologists have taken remittances as the starting point for understanding questions of family, marriage, and gender in transnational relationships (Åkesson 2011, Lubkemann 2005, McKay 2007, Pauli 2008). In some instances, even seemingly insignificant sums of money and small gifts can go a long way toward 
maintaining reciprocal kinship and social ties that ultimately provide migrants with the option to move back home when they become too old to work (Cliggett 2003). As money that moves between people, remittances lend themselves to analysis of social ties created and maintained when people feel themselves obligated to give, receive, and reciprocate (cf. Mauss 1990). And yet, though a focus on remittances may be illuminating in some contexts, in others - such as the Fouta Djallon—remittances are often practically indistinguishable from the many other transactions situated on the cusp of individual striving and collective social concern (cf. Bloch and Parry 1989). Migrants' ambitions to go abroad and seek their fortunes, even while acknowledging the severe difficulties of earning enough money to save or send home, are intimately intertwined with individual desires for social personhood. This relationship becomes clear when individual migrants' stories of earning, or failing to earn, money abroad are examined in conjunction with the barely profitable business practices of non-migrants at home, as the following sections demonstrate.

\section{Leaving a trace: the sociology of a départ}

In both the Fouta Djallon and Dakar, I frequently heard of people sending home regular sums to support their parents and other older relatives, or to support the education of children, younger siblings, and cousins. But the young Fulbe men I knew in Dakar aspired not only to support their families, but also to earn what they called a départ-effectively, a sum of money large enough to give them a start both in business and in life. In addition to the possibility of earning money, getting one's départ entailed going on an "adventure" (aventure) in the world, an adventure that many people spoke of as having an educational value. Within this popular narrative, migration to Dakar or the world beyond becomes a young man's quest for adult 
personhood. The trope of a young man going off to seek his fortune in order to return and win a bride loomed large in the Fouta Djallon. However, the cost a young man faced in getting married was significant, including the bride-price (formerly given in cattle, now usually cash), gifts of money for the bride's friends, sisters, and aunts, new clothes for the bride and other members of the family, and enormous amounts of food for the wedding celebrations. After marriage, either the new wife would number among the people to whom the migrant groom sent money, or else - if her new husband had a room with a bed, which was far more expensive to obtain in Dakar than in Guinea — she would travel abroad to join her husband, who was not required to come home for the wedding ceremony. Ideally, marriage would be followed by the births of children and the construction of a house in the groom's hometown.

These goals of getting married, subsequently having children, and building houses were not unique to migrants: Fulbe in both Guinea and Senegal spoke of these as required qualifications for anyone to be considered a responsible adult. Building houses and having children were two of the ultimate life achievements that people referred to as "leaving a trace" (laisser une trace, or accugol batte in Pular). A life lived without leaving behind some sign that a person had been on this earth was essentially a failure. But "leaving a trace" could rarely be accomplished without money, the "key to the world" cited by Lamarana, above. And though some people managed to build successful businesses without ever going abroad, the prevailing notion among Fulbe was that one could not properly get one's départ if one stayed in Guinea. Money sent and carried home from abroad had the power and recognition of foreign hard currency, unlike the notoriously weak Guinea franc. As one interviewee put it, 
Our money has no strength. It's weak. The difference is, if you work abroad [leydi porto, literally "white people land"] for five years, what you earn there is like if you worked here for thirty years.

One problem with this model was that the cost of living in Europe and North America, and even in places closer to home like Dakar, was far higher than in Guinea. A very basic room in Dakar cost at least 20,000 to 25,000 CFA francs per month in rent-about $\$ 40$ to $\$ 50$. In contrast, a similar room in Labe, the largest city in the Fouta Djallon region, might cost 20,000 to 25,000 Guinea francs per month—-from $\$ 3$ to $\$ 5$, according to the shifting exchange rates during my research period. Dakar rent prices were shocking to some migrants who, if they had ever paid for housing at all, had paid considerably less. The cost of rent, electricity, water, and food could easily consume whatever money migrants managed to earn in a month.

Examples of successful Guinean Fulbe in Dakar certainly existed. A few prosperous entrepreneurs from the Fouta Djallon ran transnational business empires, constructed multi-story buildings in suburban neighborhoods, and gave their sons and daughters university educations. (Occasionally, while walking or riding public transport with me through Dakar's neighborhoods, an informant would point to a large building and say, "A Pullo-Fouta owns that."”7) More generally, Guinean Ful6e operated most neighborhood shops in Dakar's residential areas, and they made up the overwhelming majority of the city's fruit and vegetable vendors. Soon after arriving in Dakar, I discovered that I could speak Fouta Djallon Pular to shop-owners or fruit vendors, expect to be understood, and strike up new acquaintances. Guineans in Dakar often invoked a Fulbe talent for entrepreneurship to differentiate themselves from Senegalese citizens who had migrated to the capital from the countryside. This was an ideal that women shared as 
well as men. Salimata, a Guinean vegetable vendor in Dakar, distinguished herself in this way from the ethnic Serer Senegalese laundry women who sat on the street corner opposite her vegetable stand. Though the Serer women had come from rural areas of Senegal to work in Dakar, just as Salimata and other Guinean women had come to Dakar from the rural Fouta Djallon, Salimata considered the Serer to be fundamentally different from herself. The Serer women sat on the street corner all day, hoping that residents of the neighborhood would hire them to wash laundry by hand. Salimata sat and sold vegetables that she had bought at a distant suburban market early that morning. "Fulbe don't like to work for other people, they like to work for themselves," Salimata told me. Often, this meant going into commerce. "If Fulbe can find something to sell, they will sell it. Only if they can find nothing to sell will they start working like a Serer," she concluded. Through observations like this, Salimata and other Guinean Fulbe in Dakar articulated shared notions that independence and entrepreneurship were particular and ideal attributes of a proper Fulbe person.

But running a business required start-up capital, personal connections, or both—and many migrants left Guinea with neither resources nor supportive social networks as they tried to make their way in an unfamiliar place. Fulbe unable to muster enough capital to start their own businesses, or whose businesses failed, tried to find whatever jobs they could, even if these did not conform to ideals of Fulbe work. Even Salimata, an established neighborhood vendor, urged me to hire her to clean my apartment and do my laundry when we first met. During my months in Dakar, I heard of many instances of migrants who found no work at all, and could not even raise enough money to pay their return transport to the Fouta Djallon. These cases of failure were almost never discussed or acknowledged as such in migrants' hometowns, as the following account illustrates. 
One of my informants, 25-year-old Alpha Amadou, left his hometown of Hamdallaye in the Fouta Djallon and came to Dakar during my fieldwork. Soon after his arrival, a cousin helped him get work at a palm oil warehouse in one of Dakar's markets. Every morning he would fill a plastic container with oil and carry it on his head through the marketplace and the surrounding neighborhoods, trying to sell one liter or half-liter at a time. There were several others doing exactly the same thing, so that the number of palm oil vendors seemed far greater than interested buyers. By working all day long, he earned enough to eat his midday meal. Rarely, he made enough to eat two meals. Alpha Amadou had arrived in Dakar with his life's savings of about $\$ 1,000$, which he then lost when the cousin to whom he had entrusted the money absconded to Angola. He had not planned to sell oil from a container on his head, a kind of work he and other Fulbe considered demeaning. He hadn't realized that the young men he knew in Hamdallaye, who had gone abroad and later returned talking about the superiority of life in Dakar, had been obliged to carry their employers' merchandise on their heads, or do manual labor for small amounts of money. No one talked about this back home. In Dakar, Alpha Amadou saw men he used to know in Hamdallaye who now pretended not to recognize him; he could tell they were ashamed to be seen doing the kind of work they were doing. So he learned that when he passed a man he had once known who was now carrying a container of oil or someone else's baggage on his head, he must look aside and pretend not to see. Though rarely declared as such, failure and shame were common experiences for Ful6e migrants who found themselves unable to do work they considered respectable, let alone establish a business, and whose attempts to earn money enabled them to do little more than survive. ${ }^{8}$

Migrants like Alpha Amadou who did work they considered shameful were motivated against seemingly impossible odds by their desire to achieve enough of a fortune to bring them 
into adult personhood, toward marriage, children, a house, and "leaving a trace." Some people told admiring rags-to-riches stories about notoriously wealthy Fulbe businessmen who had come from poor families and made their départ through hard work. ${ }^{9}$ But the temporality of this scheme was critical. Many young men's willingness to suffer through particularly difficult circumstances abroad was supported by the popular notion that these difficult circumstances were only temporary — that as soon as they had earned enough money to marry and start their own businesses and adult lives back in the Fouta Djallon, they would be able to leave behind the hardship they had endured to achieve their goals. One young man emphasized in an interview that he did not especially want to be in Dakar, and hoped to return to Guinea as soon as he had the means to start a small business there:

I want to go home... But how I will go home, my wish—God knows what he's doing, [but] my wish is that I will have for myself a little money [manankun]. So if I go home, it will be to go and get a place [pilaas, i.e. a restaurant or shop]. If today I got the money to get a place, even a small one, even a little café, I'd get it in Guinea.

The rapidity or slowness of money earning was a part of this idealized temporality. Most people recognized that earning money cleanly and honestly must be a gradual process. Many informants associated the swift accumulation of riches with illegal activities like drug dealing, prostitution, stealing, and sorcery. Selling alcohol, though legal according to state laws, was illegal according to Islam and regarded in virtually the same light as selling drugs. In some cases, the widespread truism that honest money could only be earned gradually served as a defense for Fulbe working abroad who had not sent significant gifts or sums of money home to their parents. 
According to one anecdote I heard, an elder man in Daande Caanguel reproached his son in England for not having provided him with the things that other elders in town had received from their children working abroad — new houses, cars, and pilgrimages to Mecca. The son in England replied that he could give his father all of those things very quickly — if he started to sell drugs. But otherwise, they would all have to wait, while he earned money slowly and honestly, according to ideals of Fulbe propriety. The gradual timing of honest money-earning helped to explain and moderate the failures that many migrants experienced; failures could be interpreted not in absolute terms, but rather as temporary setbacks within the long and possibly indefinite process of striving for financial and personal success.

The adventures of young Fulbe male migrants in Dakar and elsewhere in the world are in some ways heroes' quests, following in a tradition of West African epic figures who leave home to embark on risky undertakings, ultimately for the collective benefit of their kin and home communities (Bird and Kendall 1980). Pular speakers describe migrants as going "to seek" or "to search" (dab6ugol). "He left to seek," a Fulbe parent might say of a son who had gone to Senegal or Italy or Angola. "His [and our] fortune" would be the implied object of the search, but so would "his [and our] future." A hero son returned from adventure would see to his parents' comfort, marry a local bride, have children, and build a house — effectively, transition to adult personhood. And yet, at best, the process of leaving these "traces" would likely take many years and multiple return trips. In many cases, as Mamadou Korka asserted in the exchange with which I opened this paper, “people leave Guinea and try for twenty years to make money and they don't succeed." Discussing the hardships experienced by migrants to the Indonesian island of Batam, Johan Lindquist points out that "what is initially imagined as a rite of passage does not necessarily lead to a resolution" (Lindquist 2009:12). This sentiment would have resonated with 
many Guinean Fulbe men in Dakar who after years of striving had yet to get their départ. Furthermore, though migrants from the Fouta Djallon traveled frequently to Dakar, poststructural adjustment Dakar was less a site of economic opportunity than itself a city of emigration, a transit point from which large numbers of Senegalese, Guineans, and other West Africans sought to move onward to more distant corners of the world—even via clandestine and extremely dangerous fishing boat voyages to Europe (Melly 2011).

While some young men like Alpha Amadou were unpleasantly surprised at the working conditions they discovered in Dakar, others, like Mamadou Korka, spoke as though success for Guineans abroad were practically impossible. And yet, despite at least a partial awareness of the challenges involved, Fulbe with few or no resources have continued to leave the Fouta Djallon to seek a départ elsewhere. One elderly woman in Hamdallaye explained the situation bluntly and succinctly:

"What's making people here leave and taking them abroad? The money there is strong. If they go there and make money, they'll come back and exchange it. They'll buy land, they'll build villages, they'll bring cars. This is the main advantage of going. Today, whoever doesn't go abroad will be incapable, useless."

This fearful prospect of being generally regarded as "incapable" (keldaa) or "useless" (hittaa) motivated many Guinean Ful6e, especially men, to seek their fortunes abroad. Migrants faced slim odds of economic success; they might rarely send remittances, and they might experience personal shame from the nature of the work they were obliged to do. But to live life at home without a means of earning any money, and consequently without any means of proving oneself 
"capable" and of "leaving a trace," meant almost certain failure at becoming a responsible

person. And while failure abroad might be hidden from families and communities at home, failure at home happened in full view of the very people to whom one was unable to fulfill one's obligations. Under these circumstances, people who were obliged to stay home often did work that earned little or no money, but that nevertheless demonstrated their responsible personhood to others.

\section{More than just sitting around, but less than earning a living: evading "uselessness"}

"In Guinea, you'll see young people, maybe fifteen people, twenty people, even thirty people, sitting from seven o'clock in the morning to seven o'clock at night, or even until eight, or nine, or ten, or midnight. They'll be making tea, playing checkers, telling jokes..."

--Guinean Fulbe man in Dakar, March 2010

Young people in the Fouta Djallon, and indeed throughout many areas of Sahelian West Africa, sometimes enjoy sitting and talking in a group while drinking tea brewed in three rounds from a common pot (cf. Masquelier 2013). This popular social activity, which can take the better part of an afternoon, was a subject of critique among many Fulbe, as the informant quoted above implies. Whereas this man had embarked on a quest to seek his fortune and his future, those remaining in his hometown were—in his estimation— just sitting around, and not working. The frequent characterization of youth as "just sitting around" (joodagol tun) was consistent with a larger collective self-critique that Fouta Djallon residents frequently directed against themselves when comparing Guinea with other postcolonial states they considered more developed. Once, during my research in Hamdallaye, a schoolchild's notebook cover printed with color 
photographs of Dakar street scenes and the English words "Dakar New Look" became the subject of much admiration among a group of men who were themselves sitting and making tea. Commenting on the roads and buildings in the photos, the men all discussed how in Senegal, people worked - not like here, in Guinea. Deploying unflattering stereotypes, this rhetoric of "rueful self-recognition" helped bind Fouta Djallon residents together in a kind of "cultural intimacy," while simultaneously blaming them for national problems (Herzfeld 2005). At the same time, some individuals who found themselves unable to either migrate and send home remittances, or earn a living through work in the Fouta Djallon nevertheless went to significant lengths to demonstrate that they were not "incapable" or "useless." In order to show their families and communities that they were, or were becoming, responsible adult persons, both men and women occupied themselves with entrepreneurial ventures that counted as respectable work, even when their efforts yielded little or no profit. Like Weber's Protestants, people in the Fouta Djallon recognized hard work and striving for economic success as signs of virtue (cf. Weber 2003). ${ }^{10}$ But far from achieving wealth through capitalist accumulation, most individuals working in the Fouta Djallon managed, at best, to forestall allegations of social "uselessness."

For the majority of people in Guinea, as one informant put it, "Fin de mois alaa"essentially, "there is no payday." Guinean civil servants got paid at the end of the month, but these people were few in comparison with the population as a whole. Even government functionaries and teachers who in principle did receive monthly salaries rarely found their incomes either reliable or sufficient. Salary payments were often delayed, and during periods of national insecurity banks closed for long stretches, the money inside rendered inaccessible. Salary levels were paltry compared with most households' expenses, especially in a context of rampant inflation and rising prices of basic necessities like food staples and gasoline. A woman I 
knew in Hamdallaye had worked as a schoolteacher since 1970. In 2010, after forty years in the same job, her salary was less than one million FG (in late 2010, about \$150) per month. With the price of a 50 kilogram sack of rice approaching $250,000 \mathrm{FG}$, and a large household of people who could finish 50 kilograms of rice in little more than a week, her salary alone was barely enough for basic survival. Meanwhile, teachers and other government functionaries without her seniority were obliged to make do with even lower salaries. ${ }^{11}$ And although Guineans who worked for international organizations and foreign embassies could count on being paid more regularly than those working in the public sector, their salaries were generally commensurate with what a comparable Guinean institution would have paid them - thus much less than that of their expatriate co-workers, and in Guinea francs rather than foreign hard currency. When the exchange rate plummeted, so did their salaries' buying power.

People without salaried jobs, for whom there truly was no payday, managed to get by (se débrouiller, or débrouillugol in the Pular adaptation of the French verb) by patching together a combination of income-generating schemes. Remittances from relatives abroad might regularly or occasionally supplement money earned through local business projects, but people receiving remittances rarely allowed them to replace their entrepreneurial endeavors; instead, people spoke of money sent from migrant relatives as providing them with the means to invest and expand their business efforts. Beginning as teenagers — and sometimes even before-most people in the Fouta Djallon were in the process of figuring out how to make money in conditions that were unpromising at best. But though surviving, let alone prospering, could be difficult, most individuals were not willing to do just any kind of work; if possible, they directed their efforts toward entrepreneurship, in keeping with the notion—sometimes implicit, sometimes stated outright - that Fulbe were especially skilled in this area. Few people had disposable income of 
any kind, and profit margins were small. Nevertheless, business was the ideal, much preferred to farming, which some Guinean politicians argued would be more beneficial in developing the country. Some Fouta Djallon residents explained the supposed Fulbe distaste for agriculture as rooted in the Fulbe legacy of nomadic pastoralism, though few Fulbe in Guinea today rely on their animals for their livelihood. Most Fouta Djallon women kept home gardens, multi-cropping cassava, maize, taro, sweet potatoes, peanuts, squash, and other vegetables for home consumption. But large-scale agriculture was associated with lower-status social groups rather than Fulbe, who preferred commerce. ${ }^{12}$ A typical business plan involved opening a small shop to sell items that people bought on a daily basis, like soap, candles, batteries, tomato paste, and tea. But this kind of venture was only an option for those who had already gotten a départ, or whose family members, within Guinea or abroad, could provide start-up funds. Others had to think of more creative entrepreneurial approaches.

Some enterprises that required little start-up capital could be surprisingly profitable. In Daande Caanguel, I got my daily water supply from Abdourahmane, a man in his mid-forties. Working with about a dozen of his own plastic jerrycans and a cart, Abdourahmane spent his days ferrying water from the town pump to his regular customers. Abdourahmane would pour the water from two of his jerrycans into my own two personal jerrycans, empty from the previous day's use. I paid him the going rate of 500 FG per jerrycan. If he managed to deliver a hundred jerrycans of water a day, Abdourahmane made 50,000 FG (\$7-\$8). This worked out to be $1,500,000 \mathrm{FG}$ (about \$230) a month-more than the salaries of many government functionaries. Abdourahmane's work was distinguished from the manual labor performed by Guinean migrants in Dakar because Abdourahmane operated his own business rather than 
working for someone else. Nevertheless, the hard physical labor of carrying water for others did not appeal to most young, male Fulbe as a business plan.

Cases like Abdourahmane's notwithstanding, most people did work that seemed hardly worth the effort, so small were the profits involved. A young married woman I knew in Hamdallaye made snacks — tiny meatballs, fishballs, and beignets - to sell at the village's weekly market. With each item selling at 100 or $200 \mathrm{FG}$, she might bring in 35,000-37,000 FG (\$5-\$6) by the end of the day — barely more (and sometimes less) than she had spent on ingredients. One government functionary in Daande Caanguel supplemented his unreliable salary by selling mobile phone recharge cards. For every 92,000 FG (about \$14) in recharge cards he sold, he got to keep $1,500 \mathrm{FG}$ (less than $\$ 0.25$ ). With lots of competitors selling the same cards, and with many customers buying cards in small, 1,000 FG and 2,000 FG increments, earning money this way was slow. In a good month, he might sell 4 million FG in recharge cards, earning about $65,000 \mathrm{FG}$ (about $\$ 10$ ) for himself. In months when local mobile phone coverage was spotty or nonexistent for several days at a time — not an uncommon event—he earned much less. Daouda, a high school student in Hamdallaye, occupied himself during his 2010 summer vacation by selling gasoline by the liter out of repurposed gin bottles. On the one hand, he could be sure of selling all the gas he acquired; inexpensive Chinese-manufactured motorbikes were increasingly popular even in rural areas, and the closest official gas station was in Labe, some twenty kilometers away. Daouda had two twenty-liter plastic jerrycans, which he would take to Labe and fill with gasoline at the station pump for the official price of 6,500 FG (about \$1) per liter. Back in Hamdallaye, Daouda would pour the gas from the jerrycans into individual liter bottles and display them by the side of the road, for sale at the local black market rate of 7,500 FG per liter. This was a profit of 20,000 FG (about \$3) per jerrycan, 40,000 FG for both, but that profit 
was immediately halved if Daouda traveled to Labe to buy the gas himself-his seat in a shared taxi would cost 10,000 FG each way. Daouda got around this by commissioning taxi drivers traveling between Hamdallaye and Labe to take his empty jerrycans to the gas station and fill them for him, for a fee of 2,500 FG per jerrycan. Daouda estimated that he sold between four and six jerrycans-worth of gasoline in a month, clearing a profit of between 70,000 FG-105,000 FG (\$10-\$16) if he refrained from traveling to Labe at all himself. While this was not a bad summer income for a high school student who lived and ate with his family, Daouda would never have been able to support himself, let alone save for marriage or start building a house, relying on his gas money.

Small enterprises like these might appear irrational. People made only meager amounts of money, and sometimes even failed to break even, and yet persisted in this work. Why? Those who did otherwise - those who appeared to be sitting around and not working — could face widespread censure for failing to fulfill their responsibilities as adult persons. To "just sit" (joodagol tun) was no good, Fouta Djallon residents told me on numerous occasions. Many, even most people operated on a middle ground between failure and success, doing more than just sitting around, but less than earning a living. People who never made what they considered a départ, or whose moments of financial prosperity had come and gone, nevertheless worked according to ideals not only of what was profitable, but of what was socially acceptable and laudable. If they could be seen to be working industriously, they could be seen as responsible persons, rather than as "incapable" (keldaa) or "useless" (hittaa).

This was especially the case for women, who rarely risked criticism from their families or the public by sitting around a teapot and not working. ${ }^{13}$ Patrilocal marriage patterns in the Fouta Djallon meant that young married women often lived in households with their husbands' parents, 
brothers, and brothers' wives, where they were responsible for work including cooking, cleaning, gardening, and taking care of their own and others' children. In theory, a husband would give or send his wife regular sums of money to support the household, but this was contingent upon his earnings, which might be insufficient or sent infrequently. Consequently, women did not worry like men about getting a départ to afford marriage, but they incurred a number of expenses and obligations after marriage, often struggling to feed and clothe their children and send them to school, while also supporting aging parents. Activities like selling snacks at weekly market days might or might not enable women to meet some of these financial obligations, but they did allow women to demonstrate to their husbands' families and to their larger communities that they were working, and not "just sitting" around.

For both women and men in the Fouta Djallon, small-scale business efforts like selling market snacks, phone recharge cards, or gasoline by the liter demonstrated a sense of responsibility and personhood but yielded little to no profit. Often, these efforts were "informal," in that they were not registered with any government entity, followed no official regulations, and paid no taxes (cf. Hart 1973). Outside traditional regulatory structures, informal economic activities may involve creativity and ingenuity, with people constantly on the lookout for entrepreneurial opportunities. Nevertheless, in Guinea and in other contexts of structural poverty, people can only afford to pursue business opportunities on a small scale; and those working at informal economic activities often survive only just barely, postponing rather than preventing total financial meltdown (cf. Hart 1973:79-81).

If they earned little money, however, people who engaged in small-scale, informal commerce showed their families and communities that they were responsible persons who worked hard to manage difficult living conditions as best they could. Under the structural 
constraints of poverty and underdevelopment, as well as the shared ideals that privileged entrepreneurship rather than manual labor or farming as acceptable work for Fulbe, Fouta Djallon residents endeavored not to be socially "useless" but rather to demonstrate their capability. Those who went abroad to seek their fortunes, meanwhile, through their absence avoided exposing themselves to accusations that they were "just sitting around" and not working. Even if young Fulbe in Senegal did sometimes sit and drink tea, like Alimou, Mamadou Korka and their peers in this article's opening vignette, their sitting was invisible to their families and hometowns.

\section{Conclusion: In search of personhood abroad and at home}

For people growing up in the Fouta Djallon, the notion of going abroad "to seek" represents one of the most attractive paths to personal success. Visible traces of other migrants' achievements, especially in the form of houses and other constructions, shape the physical environment and provide ideal models of what work abroad makes possible. Money sent or brought home from abroad affirms the possibility of success through transnational migration. And yet, for many people, migration is an experience of disappointment. Dreams of making money to get a départ go unfulfilled, and instead of pursuing independent business ventures, migrants are often obligated to take up manual labor and other work they consider shameful. Sometimes, they have little to do but "just sit" and drink tea, inactivity for which they would have been criticized at home. However, despite this disappointment, many people in the Fouta Djallon consider the best option for enduring poverty and insecurity at home to be seeking their fortunes — and thus their adult lives—abroad, even after multiple failures and setbacks. 
At some level, the difficulties that Guineans and others confront in transnational migration can be read as a consequence of growing global inequalities and obstructions preventing the movement of people to and from certain areas of the world. Even as Guineans and migrants from many other countries have continued to see mobility as a way toward moneyearning and personal success, national borders have become increasingly policed in the name of nationalism and security (Fassin 2011). Over the past decades, most citizens of African countries have benefited little from the flows of money, goods, and people supposed to be characteristic of neoliberalism, and restrictions have become increasingly tight on the movement of Africans into other world regions (Ferguson 2006). While many Guineans continue to express the desire to go to Europe or North America, the reality is that increasingly stringent visa policies have made Western countries largely inaccessible to most West Africans. Those who do not already have strong family connections, academic scholarships, or plausible asylum claims are unlikely to obtain even tourist visas to North America or Europe. Under these circumstances, young Guinean Fulbe have told me, they are willing "to go anywhere." For entrepreneurs looking to do business, China and Dubai have become major hubs (cf. Haugen 2012, Lyons et al. 2012). For many would-be migrants, so-called "South-South" migration, especially movement from one African country to another, seems most promising (Whitehouse 2012). In Angola, oil and diamond wealth have attracted much foreign investment and enriched a small percentage of the population, and Angola has consequently gained a reputation among Guineans as a place with dollars just waiting to be earned. And yet, for many Guineans, reaching African countries beyond the sub-region is nearly as difficult as getting to Europe or the U.S. I met men in Guinea who had braved the distance and expense of the journey to Angola only to be imprisoned and deported back to West Africa after their arrival. Migration to Senegal and other neighboring 
countries remains an option for Guineans intent to go abroad, but with persistent poverty in the wake of structural adjustment, recent and in some cases ongoing violent conflict, and, most recently, an Ebola epidemic, opportunities in the sub-region are limited. With the latitude to pursue their own survival strategies inhibited by global exclusions and structural inequalities, Guineans have been both participants in and victims of the supposed free markets and global flows of neoliberalism (cf. Han 2012, Ong 2006, Elyachar 2005).

Clearly, adverse structural conditions play a significant role both in motivating economic migrants to leave their homes in the first place, and in constraining their chances of success abroad. However, by examining instances of failed or disappointed migration together with the kinds of time-consuming yet unprofitable work undertaken by non-migrants at home, a more nuanced picture emerges in which the search for money is closely interconnected with the search for respectable adult personhood. Migration from one poor country to another might seem economically irrational, and unprofitable entrepreneurial ventures might seem badly planned, but when examined together, these patterns become understandable as individual strategies for demonstrating one's capacity to become a responsible person. My Fulbe interlocutors in Guinea and Senegal sought to become responsible persons and "leave a trace" in the world by marrying, building houses, and having children. Remittances are part of this ideal life trajectory, but they blend in with a host of other social expectations. Earning money abroad is important, and migrants consider themselves obligated to support their parents, siblings, and children financially by sending money home when they can. But adult women and men who never leave their hometowns express the same obligations to their kin, whether they are able to fulfill them by earning money or not. And when migrants do send money home, they are interested not only in supporting the daily lives or education of close relatives, but also in advancing their own 
personal futures as responsible adults who build houses, parent children, and support families. Meanwhile, to prevent friends and neighbors from judging them useless and incapable, people living in their hometowns engage in small-scale entrepreneurial ventures that allow them to do little better than break even. Critical ethnographic studies have highlighted the importance of understanding migration not only in political and economic terms, but also as a social process that shapes selves, communities, and nations (e.g. Lindquist 2009, Chu 2010, Melly 2011). Examining instances of economically failed migration in juxtaposition with unprofitable business practices among non-migrants moves this discussion further beyond a focus on remittances as the intended object of migration and toward a more textured understanding of how apparent striving allows individuals to present themselves as responsible social persons, even in contexts where economic success seems unlikely.

Both at home and abroad, people living on the edge of survival work to achieve a semblance of respectable personhood. This can be a long and contingent process, as people remain on the lookout for any opportunity that could give them a start in life. Within days or weeks of my conversation with Alimou, Mamadou Korka, and the other young men around the teapot, some of them may have found work in Dakar, others may have found a way further abroad beyond Senegal, and still others probably returned to Guinea. Alpha Amadou, the palm oil vendor, returned to Guinea after only a few months in Senegal. The following year he went to Abidjan, Côte d'Ivoire, to try his luck again there. In 2012, still looking for a way forward, he moved to Conakry and, with $\$ 15,000$ pooled from family members, traveled to Dubai to buy merchandise to sell back in Guinea. As long as he continued to seek his fortune according to the ideals he shared with others in his hometown, he could prevent—or at least postpone — not only economic failure but also a future of being considered an incapable, useless person. 
${ }^{1}$ I have changed the names of all individuals to protect their anonymity.

${ }^{2}$ Senegal and other countries in the sub-region are common migration destinations for people in the Fouta Djallon, as are France, Guinea's former colonial power, and the United States. However, since I first began working in Guinea in 2002, I have heard people mention as migrant destinations - and met people who have lived in — virtually every country in Western Europe, Canada, Australia, Japan, North African countries including Libya, Algeria, and Morocco, most countries throughout West Africa, and some central and southern African countries, especially Angola. China and Dubai have become popular commercial travel destinations for traders who go to buy merchandise.

${ }^{3}$ For the sake of consistency, I use the term "Fulbe" to refer to Pular language speakers in and from the Fouta Djallon region of Guinea. However, ethnicity in Guinea and the surrounding region is complex. Pular-speaking nomadic herders began moving into the Fouta Djallon possibly as early as the $13^{\text {th }}$ century, coexisting with different groups of sedentary farmers. In the $18^{\text {th }}$ century, Muslim Fulbe nobles and clerics engaged in a holy war and subsequently 
established an Islamic theocracy, ruling over "captives" of mixed ethno-linguistic origins until the French conquest of 1896 . Today, virtually all Fouta Djallon residents speak Pular as their first language, but historical status differences remain important. A number of classic and contemporary ethnographies have been written about related groups of people known variously throughout West and Central Africa as Fula, Fulani, Peul, Wodaabe, and Haalpulaar'en, speaking languages called Pular, Pulaar, and Fulfuulde (e.g. Stenning 1959, Dupire 1962, Regis 2003).

${ }^{4}$ Though movement across national borders was heavily restricted during first president Sekou Touré's 26-year rule, estimates suggest that about two million people had left the country by the time he died in office in 1984 (Kaba 1985:178). I have analyzed the links between historiographies of Fulbe nomadic mobility, socialist era political exile, and contemporary economic migration elsewhere (Fioratta 2013).

${ }^{5}$ The population of "Daande Caanguel" was approximately 16,000 at the time of my research, and that of "Hamdallaye" around 1,500. The Guinean (understood to be mostly Fulbe) population of Dakar probably numbered in the tens of thousands. Many of my informants claimed that between one and two million Guineans lived in Dakar, but the entire population of Dakar and its surrounding areas is around two million.

${ }^{6}$ According to World Bank studies, the cost of sending remittances to most world regions has decreased in recent years, but remains high for Sub-Saharan African countries. The cost of sending \$200 averages 12 percent for Sub-Saharan Africa, but only 8 percent for other developing regions. The cost of sending remittances from one Sub-Saharan African country to another, "if permitted at all, tends to be even higher" than remittances sent from outside the region (Ratha et al. 2011:5-6). For migrants who can afford to send only smaller sums, the cost 
of an entire transaction may be doubled by fees: during my 2009-2010 fieldwork, sending \$20 via Western Union or Moneygram from Dakar to Conakry cost over \$20.

7 "Pullo" is the singular of "Fulbe," while "Pullo-Fouta" and "Fulbe-Fouta" are terms by which Pular speakers from the Fouta Djallon frequently refer to themselves.

${ }^{8}$ The willingness of Fulbe migrants to do forms of labor abroad that they would have been ashamed to do at home is similar to the practices of West African migrants in other contexts (Newell 2012: 68-73, Whitehouse 2012: 84-90).

${ }^{9}$ A 2012 article in the news magazine Jeune Afrique profiles the activities of shoeshine boys in Conakry, most of whom are Pular speakers from the Fouta Djallon who come to the city to do menial (though entrepreneurial) work and live in humble conditions, with dreams of eventual grand success, modeling themselves on these same famously wealthy businessmen (Sow 2012). ${ }^{10}$ I frequently heard North American and European expatriates in Guinea complain that Fouta Djallon residents had fatalistic attitudes toward life and work, resigning themselves to God's will in all matters. The significance of divine authority and the hope that the suffering of this world (aduna) will be followed by rewards in the afterlife are salient concepts in the Fouta Djallon; this is perhaps especially the case for women, whose agency is circumscribed in ways that men do not experience (Smid 2010). Nevertheless, the desire for an afterlife in paradise and the desire for success in this life are complementary rather than mutually exclusive.

${ }^{11}$ The military offers one of the main salaried job opportunities in Guinea, with a possibly inflated estimate of 45,000 soldiers in 2010 (International Crisis Group 2010). However, Fulbe are significantly underrepresented in the military. 
${ }^{12}$ Some Fulbe in the Fouta Djallon do practice agriculture, but many associate it with the lower status descendants of theocratic-era "captives," as well as with the communal labor obligations of Sekou Touré's socialist government.

${ }^{13}$ Mains (2007) describes a comparable dynamic among youth in Addis Ababa, where young men sit around in cafés and talk about having too much time on their hands, while young women spend their days doing housework and wish they could spend time drinking coffee with friends. 


\section{References cited}

Åkesson, Lisa

2011 Remittances and Relationships: Exchange in Cape Verdean Transnational Families. Ethnos 76(3):326-347.

Baker-Cristales, Beth

2008 Magical Pursuits: Legitimacy and Representation in a Transnational Political Field. American Anthropologist 110(3):349-359.

Baldé, Mamadou Saliou

1976 Un Cas Typique de Migration Interafricaine: L'Immigration des Guinéens au Sénégal. In Les Migrations Africaines: Réseaux et Processus Migratoires. M. Aghassian, J.-L. Amselle, M. S. Baldé, and M. Fièloux, eds. Pp. 63-98. Paris: François Maspero.

Bird, Charles, and Martha B. Kendall

1980 The Mande Hero: Text and Context. In Explorations in African Systems of Thought. I. Karp and C. S. Bird, eds. Pp. 13-26. Bloomington: Indiana University Press.

Bloch, Maurice, and Jonathan P. Parry

1989 Introduction: Money and the Morality of Exchange. In Money and the Morality of Exchange. J. P. Parry and M. Bloch, eds. Pp. 1-32. Cambridge: Cambridge University Press.

Carsten, Janet

1995 The Substance of Kinship and the Heat of the Hearth: Feeding, Personhood, and Relatedness among Malays in Pulau Langkawi. American Ethnologist 22(2):223-241.

Chu, Julie Y. 
2010 Cosmologies of Credit: Transnational Mobility and the Politics of Destination in China. Durham: Duke University Press.

Cliggett, Lisa

2003 Gift Remitting and Alliance Building in Zambian Modernity: Old Answers to Modern Problems. American Anthropologist 105(3):543-552.

Cohen, Jeffrey H.

2011 Migration, Remittances, and Household Strategies. Annual Review of Anthropology 40(1):103-114.

Coulter, Chris

2009 Bush Wives and Girl Soldiers: Women's Lives through War and Peace in Sierra Leone. Ithaca: Cornell University Press.

Dupire, Marguerite

1962 Peuls Nomades. Étude Descriptive des Wodaabe du Sahel Nigérien. Paris: Institut d'Ethnologie.

Elyachar, Julia

2005 Markets of Dispossession: NGOs, Economic Development, and the State in Cairo. Durham: Duke University Press.

Fassin, Didier

2011 Policing Borders, Producing Boundaries. The Governmentality of Immigration in Dark Times. Annual Review of Anthropology 40(1):213-226.

Ferguson, James

2006 Global Shadows: Africa in the Neoliberal World Order. Durham: Duke University Press. Fioratta, Susanna 
2013 States of Insecurity: Migration, Remittances, and Islamic Reform in Guinea, West Africa. Ph.D. dissertation, Department of Anthropology, Yale University.

Fortes, Meyer

1973 On the Concept of the Person Among the Tallensi. In La Notion de Personne en Afrique Noire: Colloques Internationaux du Centre National de la Recherche Scientifique. R. Bastide and G. Dieterlen, eds. Pp. 282-319. L'Harmattan.

Green, Paul

2011 The Enemy Within? Explorations of Personhood, Friendship and Difference amongst Brazilian Nationals in Japan. Journal of Ethnic and Migration Studies 37(3):373-388.

Grigolini, Silvia

2005 When Houses Provide More Than Shelter: Analyzing the Uses of Remittances within Their Sociocultural Context. In Migration and Economy: Global and Local Dynamics. L. Trager, ed. Pp. 193-223. Walnut Creek: AltaMira Press.

Han, Clara

2012 Life in Debt: Times of Care and Violence in Neoliberal Chile. Berkeley: University of California Press.

Hansen, Karen Tranberg

2005 Getting Stuck in the Compound: Some Odds Against Social Adulthood in Lusaka, Zambia. Africa Today 51(4):3-16.

Hart, Keith

1973 Informal Income Opportunities and Urban Employment in Ghana. Journal of Modern African Studies 11:61-89.

Haugen, Heidi Østbø 
2012 Nigerians in China: A Second State of Immobility. International Migration 50(2):65-80. Hernandez, Ester and Susan Bibler Coutin

2006 Remitting Subjects: Migrants, Money and States. Economy and Society 35(2):185-208. Herzfeld, Michael

2005 Cultural Intimacy: Social Poetics in the Nation-State. New York, London: Routledge. International Crisis Group

2010 Guinea: Reforming the Army. Dakar/Brussels: ICG Report Afrique No164, September 23.

Jackson, Michael and Ivan Karp

1990 Introduction. In Personhood and Agency: The Experience of Self and Other in African Cultures. M. Jackson and I. Karp, eds. Pp. 15-30. Washington, DC: Smithsonian Institution Press.

Jeffrey, Craig

2010 Timepass: Youth, Class, and Time among Unemployed Young Men in India. American Ethnologist 37(3):465-481.

Kaba, Lansine

1985 A New Era Dawns in Guinea. Current History 84(501):174-187.

La Fontaine, Joan

1985 The Person and Individual: Some Anthropological Reflections. In The Category of the Person: Anthropology, Philosophy, History. M. Carrithers, S. Collins, and S. Lukes, eds. Pp. 123-140. Cambridge: Cambridge University Press.

Lindley, Anna 
2010 The Early Morning Phone Call: Somali Refugees' Remittances. New York: Berghahn Books.

Lindquist, Johan A.

2009 Anxieties of Mobility: Migration and Tourism in the Indonesian Borderlands. Honolulu: University of Hawai'i Press.

Lubkemann, Stephen C.

2005 The Moral Economy of Nonreturn among Socially Diverted Labor Migrants from Portugal and Mozambique. In Migration and Economy: Global and Local Dynamics. L. Trager, ed. Pp. 257-287. Walnut Creek: AltaMira Press.

Lyons, Michal, Alison Brown, and Li Zhigang

2012 In the Dragon's Den: African Traders in Ghangzhou. Journal of Ethnic and Migration Studies 38(5):869-888.

Mains, Daniel

2007 Neoliberal Times: Progress, boredom, and shame among young men in urban Ethiopia. American Ethnologist 34(4):659-673.

Martin-Iverson, Sean

2012 Autonomous Youth? Independence and Precariousness in the Indonesian Underground Music Scene. The Asia Pacific Journal of Anthropology 13(4):382-397.

Masquelier, Adeline

2013 Teatime: Boredom and the Temporalities of Young Men in Niger. Africa 83(3):470-491. Mauss, Marcel 
1979[1938] A Category of the Human Mind: The Notion of Person, the Notion of 'Self'. In Sociology and Psychology: Essays. B. Brewster, trans. Pp. 57-94. London: Routledge \& Kegan Paul.

1990[1924] The Gift: The Form and Reason for Exchange in Archaic Societies. London: W. W. Norton.

McIntosh, Janet

2009 The Edge of Islam: Power, Personhood, and Ethnoreligious Boundaries on the Kenya Coast. Durham: Duke University Press.

McKay, Deirdre

2007 'Sending Dollars Shows Feeling': Emotions and Economies in Filipino Migration. Mobilities 2(2):175-194.

Melly, Caroline M.

2011 Titanic Tales of Missing Men: Reconfigurations of National Identity and Gendered Presence in Dakar, Senegal. American Ethnologist 38(2):361-376.

Mohan, Giles

2008 Making Neoliberal States of Development: The Ghanaian Diaspora and the Politics of Homelands. Environment and Planning D: Society and Space 26:464-479.

Mohapatra, Sanket, and Dilip Ratha

2011 Remittance Markets in Africa. Washington, DC: The World Bank.

Monsutti, Alessandro

2005 War and Migration: Social Networks and Economic Strategies of the Hazaras of Afghanistan. New York: Routledge.

Newell, Sasha 
2012 The Modernity Bluff: Crime, Consumption, and Citizenship in Côte d'Ivoire. Chicago: University of Chicago Press.

Ong, Aihwa

2006 Neoliberalism as Exception: Mutations in Citizenship and Sovereignty. Durham: Duke University Press.

Pauli, Julia

2008 A House of One's Own: Gender, Migration, and Residence in Rural Mexico. American Ethnologist 35(1):171-187.

Ratha, Dilip, Sanket Mohapatra, Çaglar Özden, Sonia Plaza, William Shaw, and Abebe Shimeles

2011 Leveraging Migration for Africa: Remittances, Skills, and Investments. Washington, DC: The World Bank.

Regis, Helen A.

2003 Fulbe Voices: Marriage, Islam, and Medicine in Northern Cameroon. Boulder, CO: Westview Press.

Riccio, Bruno

2011 Rehearsing Transnational Citizenship: Senegalese Associations, Co-development and Simultaneous Inclusion. African Diaspora 4:97-113.

Riesman, Paul

1992 First Find Your Child a Good Mother: The Construction of Self in Two African Communities. New Brunswick: Rutgers University Press.

Scheld, Suzanne

2007 Youth Cosmopolitanism: Clothing, the City and Globalization in Dakar, Senegal. City \& Society 19(2):232-253. 
Smid, Karen

2010 Resting at Creation and Afterlife: Distant Times in the Ordinary Strategies of Muslim Women in the Rural Fouta Djallon, Guinea. American Ethnologist 37(1):36-52.

Sow, Alimou

2012 Guinée: Virtuoses de la Débrouillardise. Jeune Afrique, March 19.

Stenning, Derrick J.

1959 Savannah Nomads: A Study of the Wodaabe Pastoral Fulani of Western Bornu Province, Northern Region, Nigeria. Oxford: Oxford University Press.

Strathern, Andrew J. and Stewart, Pamela J.

1998 Seeking Personhood: Anthropological Accounts and Local Concepts in Mount Hagen, Papua New Guinea. Oceania 68(3):170-188.

Trager, Lillian

2001 Yoruba Hometowns: Community, Identity, and Development in Nigeria. Boulder, CO: Lynne Rienner Publishers.

Weber, Max

2003[1920] The Protestant Ethic and the Spirit of Capitalism. Mineola, NY: Dover Publications.

Whitehouse, Bruce

2012 Migrants and Strangers in an African City. Bloomington: Indiana University Press. World Bank

World Bank

2011 Migration and Remittances Factbook 2011. http://go.worldbank.org/QGUCPJTOR0 (Accessed October 19, 2013). 
